\title{
Perspektywy badań poświęconych rosyjskiej filozofii religijnej podczas I wojny światowej
}

\author{
DOI 10.35757/CIV.2016.18.19
}

Michał Bohun: Oczyszczenie przez burzę. Włodzimierz Ern i moskiewscy neosłowianofile wobec pierwszej wojny światowej, Wydawnictwo Uniwersytetu Jagiellońskiego, Kraków 2007.

\section{Wprowadzenie}

W latach 1914-1917 wielu autorów związanych $z$ rosyjskim renesansem religijno-filozoficznym poszukiwało formuł pozwalających opisać duchowa podstawę I wojny światowej. Łaczyło ich przekonanie, które Mikołaj Bierdiajew sformułował następujacco: „Wojna nie jest źródłem zła, a jedynie jego odbiciem, znakiem istnienia wewnętrznego zła i cierpienia. Natura wojny jest symboliczna. Taka jest natura wszelkiej materialnej przemocy - ona jest zawsze

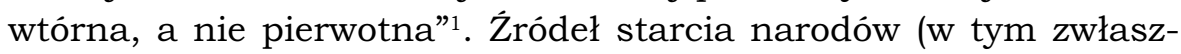
cza organizującego centralna oś wojny konfliktu Rosji z Niemcami) rosyjscy filozofowie religijni poszukiwali w odrębnej konstytucji ideowej wroga, a za cel działań zbrojnych uznawali ustanowienie ogólnoludzkiej jedności. $Z$ tego powodu uważali, że zrozumienie wojny wymaga sięgnięcia do wykładni filozoficznej.

Lata I wojny światowej współtworzą także jeden $z$ najważniejszych etapów w rozwoju rosyjskiej filozofii religijnej. Gdyby bowiem chcieć sformułować ogólna periodyzację tego rozwoju, wówczas należałoby wyróżnić lata 1905-1917, które stanowią okres nie tylko łatwo dający się wyodrębnić w historii politycznej Rosji, lecz także

1 Н.А. Бердяев: Мысли о природе войны, w: idem: Русская идея. Судьба России, Издательство В. Шевчук, Москва 2000, s. 375 [przekład własny - Т.Н.]. 
- w dziejach jej kultury umysłowej. Rosyjska filozofia religijna tego czasu została zdominowana przez dwie charakterystyczne tendencje, które pozostaja w ścisłym związu ze sobą: próbę znalezienia własnej, oryginalnej drogi oraz krytyczne zmagania ze spuścizna filozofii niemieckiej. Swój punkt kulminacyjny osiagnęły one podczas I wojny światowej lub bezpośrednio przed nią. Co ważniejsze, ta zbieżność czasowa nie dotyczy zjawisk równoległych, pozbawionych wewnętrznego związu - między wojna a rozwojem rosyjskiego renesansu religijno-filozoficznego istnieje wiele punktów stycznych, które skłaniaja do podjęcia szeroko zakrojonych badań nad wojennymi kontekstami twórczości rosyjskich filozofów religijnych $z$ lat $1914-1917$.

Celem mojego artykułu jest określenie perspektyw i zadań stojących przed badaniami poświęconymi rosyjskiej filozofii religijnej podczas I wojny światowej. W polskiej literaturze przedmiotu, w której niemało miejsca poświęcono wnikliwym analizom najważniejszych dzieł napisanych w tym czasie, takich jak Sens twórczości Mikołaja Bierdiajewa czy Światłość niezachodzaca ${ }^{2}$ Sergieja Bułgakowa, niezwykle rzadko ujmowano lata 1914-1917 jako ważny okres w rozwoju rosyjskiego renesansu religijno-filozoficznego. Właściwie tylko jedna monografia - Oczyszczenie przez burzę. Włodzimierz Ern i moskiewscy neosłowianofile wobec pierwszej wojny światowej, której autorem jest Michał Bohun ${ }^{3}$ - analizuje rzecz w ten sposób. Dlatego wysiłek, którego celem jest określenie kierunków dalszych badań nad filozofia rosyjską podczas I wojny światowej, powinien rozpoczać się od artykułu recenzyjnego poświęconego książce Bohuna.

Monografia Oczyszczenie przez burze została wydana w 2008 roku jako piętnasty tom $\mathrm{w}$ serii „Jagiellońskie Studia $z$ Filozofii

2 Polski przekład książki Bułgakowa Cвет Невечерний nosi tytuł Światło wieczności (zob. S. Bułgakow: Światło wieczności. Medytacje i spekulacje, przekład J. Chmielewski, Wydawnictwo Marek Derewiecki, Kęty 2010), takie tłumaczenie nie uwzględnia jednak liturgicznych konotacji tego wyrażenia. $Z$ tego powodu będę posługiwał się innym, bardziej dosłownym przekładem tytułu tej pracy Bułgakowa.

${ }_{3}$ Zob. M. Bohun: Oczyszczenie przez burzę. Włodzimierz Ern i moskiewscy neosłowianofile wobec pierwszej wojny światowej, Wydawnictwo Uniwersytetu Jagiellońskiego, Kraków 2008. 
Rosyjskiej”, która zarówno pod względem liczby wydanych pozycji, jak i ich doniosłości zajmuje pierwsze miejsce wśród wielu inicjatyw przybliżających polskiemu czytelnikowi myśl rosyjską. Jej autor należy do grona najbardziej uznanych polskich historyków filozofii rosyjskiej. Recenzowana książka, na podstawie której Michał Bohun uzyskał habilitacje, jest trzecia (i dotychczas ostatnia) w jego dorobku. Wcześniej filozof opublikował monografie zatytułowane: Fiodor Dostojewski i idea upadku cywilizacji europejskiejt oraz Kontrrewolucja i pesymizm. Filozofia społeczna Konstantina Leontjewa ${ }^{5}$, a także liczne artykuły, w tym takie, które są bezpośrednio zwiazane $z$ tematem recenzowanej publikacji ${ }^{6}$.

\section{Zakresy tematyczne książki}

Choć książka jest pomyślana jako monografia poświęcona postawom tzw. moskiewskich neosłowianofilów wobec I wojny światowej, to jednak można wyróżnić trzy zakresy tematyczne wpływające na jej kształt. Pierwszym $z$ nich jest zagadnienie intelektualnego rezonansu, który wywołała I wojna światowa, oraz jej filozoficznych konceptualizacji. Obecność tej problematyki, wykraczającej poza ścisły kontekst rosyjski, jest sygnalizowana zwłaszcza we wstępie oraz w zakończeniu, poświęconym pamięci o wojnie lat 1914-1918

\footnotetext{
4 Zob. idem: Fiodor Dostojewski i idea upadku cywilizacji europejskiej, Sląsk, Katowice 1996.

5 Zob. idem: Kontrrewolucja i pesymizm. Filozofia społeczna Konstantina Leontjewa, Wydawnictwo Uniwersytetu Jagiellońskiego, Kraków 2000.

6 Zob. m.in. idem: Włodzimierz Ern i spór o europejskość filozofii rosyjskiej, w: Z. Anculewicz, J. Sobczak (red.): Europa a Rosja. Opinie, konflikty, wspótpraca, Wydawnictwo Uniwersytetu Warmińsko-Mazurskiego, Olsztyn 2003, s. 185-203; idem: Paradoksy religijnej rewolucji. Włodzimierz Ern i Chrześcijańskie Bractwo Walki, w: W. Rydzewski, A. Ochotnicka (red.): Między reforma a rewolucją. Rosyjska myśl filozoficzna, polityczna i społeczna na przełomie XIX i XX wieku, Wydawnictwo Uniwersytetu Jagiellońskiego, Kraków 2004, s. 101-125; idem: Filozofia i propaganda. Myśl rosyjska wobec wielkiej wojny, „Roczniki Nauk Politycznych. Akademia Humanistyczna imienia Aleksandra Gieysztora” 2006, t. 8, nr 9, s. 83-99; idem: Duch słowiański $i$ "żółte zagrożenie». Azja w prognozach i przestrogach rosyjskich filozofów religijnych, „БОФІА. Pismo Filozofów Krajów Słowiańskich” 2006, nr 6, s. 103-114; idem: Myśl rosyjska i zmienne granice Europy. Studium przypadku, w: W. Rydzewski, L. Augustyn (red.): Granice Europy - granice filozofii. Filozofia a tożsamość Rosji, Wydawnictwo Uniwersytetu Jagiellońskiego, Kraków 2007, s. 67-83.
} 
i jej roli w dziejach nie tylko rosyjskiej, lecz także ogólnoeuropejskiej kultury umysłowej. Sam autor zadeklarował, że „jednym $z$ celów [...] pracy jest ukazanie doniosłości pierwszej wojny światowej dla myśli rosyjskiej, i szerzej: dla kultury intelektualnej XX wieku. Rosyjscy filozofowie nie stanowili pod tym względem żadnego wyjątku, a ich rozważania doskonale współbrzmia $z$ namysłem, jaki goraczkowo podejmowano w całej Europie i za Atlantykiem"7. Poglądy autorów, takich jak: Niall Ferguson, Ernst Jünger, Jan Patočka czy Wincenty Lutosławski, są w książce wielokrotnie przywoływane i tworza ważny kontekst, w którym zostały umieszczone badania poświęcone postawom rosyjskich filozofów wobec I wojny światowej. Intelektualne zmagania środowiska skupionego wokół Moskiewskiego Towarzystwa Religijno-Filozoficznego im. Włodzimierza Sołowjowa sa traktowane przez Bohuna jako jeden $z$ przykładów zjawiska o zasięgu ogólnoeuropejskim. Dzięki temu Oczyszczenie przez burze uwypukla organiczny związek filozofii rosyjskiej z myśla zachodnioeuropejska i tym samym podejmuje ważne $\mathrm{w}$ polskich badaniach założenie, które $\mathrm{w}$ dzisiejszej formie wprowadził do nich Andrzej Walicki ${ }^{8}$.

\footnotetext{
7 Idem: Oczyszczenie..., s. 20-21.

8 Założenie to pojawiło się już w pierwszej książce Andrzeja Walickiego i od tamtego czasu określa jego podejście badawcze: „Z punktu widzenia socjologicznego, $z$ punktu widzenia historii światopoglądów społecznych, dzieje dziewiętnastowiecznej myśli rosyjskiej sa dziedzina pasjonująca: załamuje się w nich cała historia intelektualna ówczesnej Europy, a zarazem całe bogactwo problemów, które stawiała przed myślicielami rosyjskimi specyficzna, odmienna od europejskiej rzeczywistość społeczna ich własnego kraju” (A. Walicki: Osobowość a historia. Studia z dziejów literatury i myśli rosyjskiej, Państwowy Instytut Wydawniczy, Warszawa 1959, s. 7). Zasygnalizowane w powyższym cytacie napięcie między tym, co uniwersalne a tym, co partykularne w myśli rosyjskiej, jest przez Walickiego konsekwentnie rozwiązywane w taki sposób, że krąg idei i problemów, w którym poruszają się rosyjscy filozofowie, łączy ich z zachodnia Europa (w tym znaczeniu filozofia rosyjska powstaje w wyniku recepcji idei zachodnioeuropejskich), natomiast to, co swoiste i oryginalne w myśli rosyjskiej, jest związane $z$ niepowtarzalnym kontekstem społecznym jej rozwoju. Temat ten szczegółowo omawiam w artykule Filozofia rosyjska $w$ studium "Osobowość a historia" Andrzeja Walickiego, który ukaże się w „Roczniku Historii Filozofii Polskiej” 2016, nr 9. Na tę właściwość badań Walickiego zwracają także uwagę m.in.: M. Maslin: Andrzej Walicki jako historyk filozofii rosyjskiej, przekład J. Dobieszewski, „Kronos” 2015, nr 4, s. 270; J. Dobieszewski: Empatia, dystans $i$ ani troche уныния. Profesor Andrzej Walicki a rosyjska myśl filozoficzna, w: J. Dobieszewski, J. Skoczyński, M. Bohun (red.): Wokół Andrzeja Walickiego, Wydział Filozofii i Socjologii UW, Warszawa 2009, s. 31-32.
} 
Drugim zakresem tematycznym, który można wyróżnić, jest właściwy przedmiot monografii - postawy wobec I wojny światowej przedstawicieli środowiska skupionego wokół Moskiewskiego Towarzystwa Religijno-Filozoficznego im. Włodzimierza Sołowjowa. Spośród autorów, których poglądy zostały omówione w książce, z założonym w 1906 roku Towarzystwem byli związani Włodzimierz Ern, Wiaczesław Iwanow (od 1913 roku), Sergiusz Bułgakow, książę Eugeniusz Trubieckoj oraz Mikołaj Bierdiajew, przy czym ten ostatni podczas wojny zdystansował się od poglądów reprezentowanych przez swoich kolegów i wystapił ze stanowczą polemika antysłowianofilską ${ }^{9}$. Bohun uwzględnia również pisma Wasilija Rozanowa, który sympatyzował zarówno ze słowianofilstwem, jak i z samym Towarzystwem, lecz jego członkiem nigdy nie był (na co wpłynęła niechęć liderów tej organizacji do nawiązania $z$ nim współpracy, wynikająca $z$ jego skandalicznej reputacji ${ }^{10}$, oraz Fiodora Stiepuna, który, choć wprost polemizował z poglądami wyrażanymi przez moskiewskich neosłowianofilów i nigdy nie był reprezentantem tego środowiska, zajmuje wyjątkowo ważne miejsce wśród rosyjskich filozofów piszacych o I wojnie światowej jako uczestnik działań wojennych ${ }^{11}$.

Książka Michała Bohuna może być również odczytywana jako praca poświęcona twórczości filozoficznej Włodzimierza Erna. Koleje losu i najważniejsze idee sformułowane przez autora Walki o Logos organizuja strukturę rozważań oraz zapewniaja ich spójność. Podjęta przez autora decyzja, aby szczególnie skoncentrować swoja uwage na poglądach Erna, choć może wydawać się arbitralna, jest uzasadniona przynajmniej $z$ dwóch powodów. Po pierwsze, wynika ona $z$ niezadowalającej recepcji pism Erna wśród badaczy myśli rosyjskiej, $z$ pewnościa nieodpowiadającej roli, która odegrały one w rozwoju rosyjskiego renesansu religijno-filozoficznego. Choć na relatywnie niewielką liczbę studiów poświęconych autoro-

9 Por. M. Bohun: Oczyszczenie..., s. 14-15.

${ }^{10}$ Por. ibidem, s. 16

${ }^{11}$ Por. ibidem, s. 21. 
wi Walki o Logos zwrócono uwage już w pochodzącym z 1991 roku wydaniu jego najważniejszych dzieł ${ }^{12}$, trzeba przyznać, że do dzisiaj (mimo pewnych oznak wzrastajaccego zainteresowania dorobkiem Erna ${ }^{13}$ ) ta luka w badaniach nad intelektualna spuścizna rosyjskiego Srebrnego Wieku nie została uzupełniona. Po drugie, ze względu zarówno na wyrazistość formułowanych przez niego opinii, jak i przedwczesna śmierć w 1917 roku, która zbiegła się z końcem okresu będącego przedmiotem zainteresowania Bohuna, pisma Erna stanowia szczególnie wymowne świadectwo rosyjskich poszukiwań ideowych w przededniu oraz w trakcie I wojny światowej.

\section{Zagadnienia podejmowane w poszczególnych rozdziałach monografii}

Postać Erna w omawianej rozprawie zajmuje najważniejsze miejsce, co można zauważyć w poszczególnych jej rozdziałach. Pierwszy $z$ nich, zatytułowany Rycerz rosyjskiej filozofii, prezentuje zarówno ogólny profil ideowy, jak i zarys biografii filozofa. Zostały w nim uwzględnione najważniejsze wydarzenia $z$ jego życiorysu: utworzenie Chrześcijańskiego Bractwa Walki (w 1905 roku) oraz Moskiewskiego Towarzystwa Religijno-Filozoficznego im. Włodzimierza Sołowjowa (w 1906 roku); tzw. spór o Logos, który wybuchł w 1910 roku między Ernem a rosyjskimi neokantystami; studia z zakresu filozofii, kariera akademicka i badania prowadzone nad dorobkiem włoskich ontologistów - Antonia Rosminiego i Vincenza Giobertiego; wybuch wojny i spór o jej duchowe źródła; badania nad Platonem (pierwsza część studium Nadrzędne pojmowanie Platona. Wprowadzenie do badania jego dzieł została opublikowana niedłu-

\footnotetext{
${ }_{12}$ Por. Ю. Шеррер: Владимир Франиевич Эрн, w: В.Ф. Эрн: Сочинения, Издательство „ПРАВДА”, Москва 1991, s. 3.

${ }^{13} \mathrm{O}$ wzroście zainteresowania świadczy m.in. wydany w serii „Pro et contra” obszerny, liczący ponad tysiąc stron tom poświęcony Ernowi (zob. А.А. Ермичев (red): В. Ф. Эрн: pro et contra, Издательство Русской Христианской гуманитарной академии, Санкт-Петербург 2006).
} 
go przed śmiercią Erna). Słuszna jest decyzja Bohuna, aby w tej części pracy szczególnie dużo miejsca poświęcić Chrześcijańskiemu Bractwu Walki jako „prologowi” działalności rosyjskiego filozofa.

Kolejny rozdział, zatytułowany Bitwa o Logos, został poświęcony dyskusji filozoficznej, która zainicjował opublikowany w 1910 roku artykuł Erna Kilka słów o Logosie, filozofii rosyjskiej i duchu naukowym ${ }^{14}$, stanowiący reakcję na ukazanie się pierwszego numeru międzynarodowego czasopisma „Logos”, skupiającego młodych rosyjskich neokantystów, uczniów Heinricha Rickerta. W toku prowadzonej polemiki Ern przeciwstawił nowożytny racjonalizm, którego założenia uzyskały - jego zdaniem - swój pełny wyraz w pierwszym wydaniu Kantowskiej Krytyki czystego rozumu, logizmowi, którego nazwa pochodzi od słowa Logos ${ }^{15}$. Autor Oczyszczenia przez burzę słusznie podkreślił kluczowe znaczenie tej polemiki w procesie formowania się dwóch środowisk, które uznawano wówczas za kontynuatorów słowianofilstwa i okcydentalizmu. To właśnie $z$ poglądów wypracowanych podczas tej polemiki wynikała reakcja Erna na wybuch I wojny światowej, która je radykalizowała i ześrodkowywała na jednym wrogu - Niemczech. Spór ratio z Logosem miał rozstrzygnać się w starciu zbrojnym między Niemcami a Rosja, reprezentujacymi te dwie przeciwstawne zasady.

Bohun omawia reakcję Erna na wybuch wojny w rozdziale zatytułowanym Kruppizm $i$ armaty $z$ Kant-Werke, czyli anatomia wroga. Kluczowa rolę odgrywa w nim najważniejsze wystąpienie wojenne Erna Od Kanta do Kruppa ${ }^{16}$, którym autor Walki o Logos po raz drugi wywołał dyskusję angażująca znaczną część rosyjskich filo-

\footnotetext{
${ }_{14}$ Zob. В.Ф. Эрн: Нечто о Һогосе, русской философии и научности, w: idem: Сочинения..., s. 71-108. Michał Bohun przetłumaczył fragmenty tego artykułu na język polski, zob. idem: Kilka słów o Logosie, filozofii rosyjskiej i duchu naukowym, przekład M. Bohun, w: L. Kiejzik (red.): Niemarksistowska filozofia rosyjska. Antologia tekstów filozoficznych XIX i pierwszej połowy XX w., t. 2, Ibidem, Łódź 2002, s. 221-230.

${ }_{15}$ Aby uniknać skojarzenia $z$ innym nurtem znanym $z$ filozofii dwudziestowiecznej, Michał Bohun wprowadził pojęcie „logoizmu” na oznaczenie stanowiska zajętego przez Erna, co jednak wydaje się niezbyt fortunna propozycją.

${ }_{16}$ Zob. idem: Om Канта к Kрупny, w: idem: Сочинения..., s. 308-318. Michał Bohun przethumaczył ten artykuł na język polski: zob. idem: Od Kanta do Kruppa, przekład M. Bohun, w: L. Kiejzik (red.): Niemarksistowska..., t. 2, s. 241-249.
} 
zofów tamtego czasu. W swoim referacie, często przywoływanym jako symbol filozoficznego antygermanizmu w pierwszowojennej Rosji, Ern próbował wykazać, że istnieje bezpośrednia ciagłość między wewnętrznym i zewnętrznym fenomenalizmem jako rezultatem filozofii Kanta a tym, że wola narodu niemieckiego dokonała zbiorowego samookreślenia w produkcji broni zagłady w zakładach Kruppa. Michał Bohun, przeciwstawiajac się obiegowym opiniom na temat wystapienia Erna, słusznie akcentuje jego spójność, podporządkowana próbie wykazania jedności kultury niemieckiej we wszystkich jej przejawach ${ }^{17}$. Jego argumentacja $\mathrm{w}$ pewnym stopniu zbliża się do linii obrony przyjętej przez samego Erna $\mathrm{w}$ artykule Istota niemieckiego fenomenalizmu, w którym zarzucił on swoim oponentom pominięcie faktu, że zawarta $\mathrm{w}$ referacie Od Kanta do Kruppa analiza miała charakter teoretyczny ${ }^{18}$. Bohun unika jednak sztucznego rozdzielania i uwypuklania różnicy między teoretycznym a praktycznym wymiarem referatu, charakterystycznym dla przywołanej wypowiedzi Rosjanina.

W trzecim rozdziale zrekonstruowano również spór, który wywołało wystąpienie Erna. Autor omawia reakcje Iwana Iljina, Siergieja Bułgakowa, Fiodora Stiepuna, Mikołaja Bierdiajewa, Siemiona Franka i Dymitra Mereżkowskiego. Podkreśla ponadto, że poglądy Erna, które okazały się tak kontrowersyjne, „w ówczesnej, pogrą̇̇onej w wojnie Europie, nie były niczym wyjątkowym ani pod względem treści czy stanowczości wywodu, ani też nieco propagandowej poetyki"19.

Między trzecim a czwartym rozdziałem następuje zmiana sposobu, w jaki Bohun prowadzi swój wywód. O ile pierwsze trzy rozdziały były poświęcone samemu Ernowi, a poglądy innych filozofów stanowiły jedynie tło i były uwzględniane przede wszystkim wtedy, gdy bezpośrednio lub pośrednio odnosiły się do jego stanowiska, o tyle od czwartego rozdziału opinie autora Walki o Logos, ciagle

\footnotetext{
${ }_{17}$ Por. M. Bohun: Oczyszczenie..., s. 71.

${ }_{18}$ Por. В.Ф. Эрн: Сущность немеикого френоменализма, w: idem: Сочинения..., s. 319-320.

${ }^{19}$ M. Bohun: Oczyszczenie..., s. 89-90.
} 
odgrywające naczelną rolę $\mathrm{w}$ konstrukcji wywodu, zostały umieszczone w szerszym spektrum zapatrywań innych przedstawicieli jego środowiska. Pozwala to retrospektywnie uchwycić strukturę pracy, która nie została zaprezentowana we wstępie. Po pierwszych trzech rozdziałach, w których Bohun najpierw przedstawił zarys biografii Erna, a następnie zrekonstruował jego poglądy na podstawie dwóch najważniejszych polemik, w których brał on udział, w kolejnych czterech rozdziałach omówił najważniejsze tematy podejmowane $\mathrm{w}$ pierwszowojennych publikacjach moskiewskich neosłowianofilów.

Pierwszym $z$ owych tematów jest problem relacji między Niemcami, Europa a Rosją. Poświęcony mu rozdział pogłębia zasadnicze rozpoznania dotyczące konstytucji duchowej wroga, które zostały wprowadzone wcześniej, oraz konfrontuje opinie Erna z poglądami innych przedstawicieli środowiska. Bohun zwraca uwage, że gruntownej krytyce kultury niemieckiej i protestantyzmu jako jej religijnego rdzenia towarzyszy teza głoszaca, że I wojna światowa, w której Niemcy wystapiły przeciwko innym krajom europejskim, ujawniła ich niejednoznaczne położenie w samej Europie. W tekście Czas słowianofilizuje Ern przekonywał, że problem miejsca Niemiec to główna aporia stojaca przed ówczesna Europą ${ }^{20}$. Moskiewscy neosłowianofile uważali, że wynika to $z$ właściwego niemieckiej kulturze duchowej protestantyzmu $z$ jego buntem przeciwko tradycji, dziedzictwu antyku i chrześcijańskiego średniowiecza. To $z$ jego powodu Niemcy miały oderwać się od źródeł kultury europejskiej, a wojna miała prowadzić do zastapienia powierzchownych opinii głębokim rozpoznaniem stosunku Niemiec i Rosji do dziedzictwa europejskiego. Odsłoniła ona bliskość Europy i Rosji oraz pogłębiła dystans między Europą a Niemcami.

Czas Słowian!, tytuł piątego rozdziału, stanowi wolne tłumaczenie rosyjskiego wyrażenia время славянофильствует, które

\footnotetext{
${ }^{20} \mathrm{~W}$ tekście Czas słowianofilizuje Ern przekonywał, że problem miejsca Niemiec to główna aporia stojąca przed ówczesna Europa (por. В.Ф. Эрн: Время славянофильствует. Война, Германия, Европа и Россия, w: idem: Сочинения..., s. 373).
} 
pojawia się w tekście Erna Czas słowianofilizuje, jednym z najważniejszych, jakie napisał podczas I wojny światowej. Zdaniem Bohuna dosłowny przekład tego wyrażenia na język polski odbiera $\mathrm{mu}$ jego ekspresyjna $\mathrm{moc}^{21}$. Głównym tematem tej części książki sa zaproponowane przez autorów związanych $z$ Moskiewskim Towarzystwem Religijno-Filozoficznym im. Włodzimierza Sołowjowa konceptualizacje idei słowiańskiej i wynikającej $z$ niej misji Słowian w ogólnoświatowym konflikcie zbrojnym. Celu konfliktu upatrywano w odrodzeniu kultury przez ustanowienie ogólnoświatowej jedności, w czym kluczową rolę mieli odegrać Słowianie pod przewodnictwem Rosji. Powrót słowianofilstwa to jeden $z$ zasadniczych tematów wojennej publicystyki Erna, który został podjęty przez Bułgakowa, Iwanowa i Rozanowa, a także $-z$ pewnymi zastrzeżeniami - przez Eugeniusza Trubieckoja, przywiązanego do antysłowianofilskich polemik Włodzimierza Sołowjowa i krytykujacego nacjonalizm. Ten ostatni przykład pozwala jednoznacznie określić charakter tych nawiązań do słowianofilstwa, które było reinterpretowane $\mathrm{w}$ duchu chrześcijańskiego uniwersalizmu. Bohun omawia także polemikę antysłowianofilska, która w publikacjach z lat 1914-1917 prowadził Mikołaj Bierdiajew, oraz ocenia jej podstawy. Po rekonstrukcji poglądów autora Sensu twórczości formułuje przekonujacy wniosek, że „najważniejszym motywem Bierdiajewowskiej historiozofii doby pierwszej wojny światowej" jest „idea jedności świata, a mówiąc ściślej, idea kultury ogólnoludzkiej opartej na zbliżeniu i syntezie Wschodu i Zachodu"22. $Z$ tego spostrzeżenia wynika, zdaniem autora Oczyszczenia przez burze, jedynie względne znaczenie polemiki antysłowianofilskiej, za która nie stała tak głęboka różnica stanowisk, jak ta, która sam Bierdiajew był skłonny dostrzegać. Bohun uznaje, że dotyczyła ona przede wszystkim oceny samego słowianofilstwa i jego miejsca w procesie realizacji wspólnego celu - Bierdiajew uważał, że słowianofilstwo jest sprzeczne $z$ mesjanistycznym uniwersali-

\footnotetext{
${ }^{21}$ Por. M. Bohun: Oczyszczenie..., s. 129-130.
}

${ }^{22}$ Ibidem, s. 140. 
zmem i że jest związane $z$ młodzieńczym okresem rozwoju kultury rosyjskiej23. Wojna miała zaś zdaniem autora Sensu twórczości wiązać się $z$ dojrzałościa narodu rosyjskiego, która powinna wyrazić się w przyjęciu odpowiedzialności za dzieje i ludzkość.

W kolejnej części monografii, zatytułowanej Droga ku powszechności: Konstantynopol i sprawa polska, autor omawia dwa szczegółowe zagadnienia, które podejmowali moskiewscy neosłowianofile - problem odzyskania Konstantynopola oraz pojednania $z$ Polska jako narodem słowiańskim, który został zniewolony przez Rosję. Michał Bohun rekonstruuje zarówno historyczne źródła idei odzyskania Konstantynopola oraz jej znaczenie w historiozoficznych konstrukcjach filozofów rosyjskich, jak i powracający w ich pismach temat odkupienia historycznej winy wobec Polski. Autor Oczyszczenia przez burze prezentuje i konfrontuje stanowiska wobec kwestii polskiej, które zajmowali myśliciele znajdujacy się w kręgu jego zainteresowań.

W ostatnim rozdziale książki, zatytułowanym Okrucieństwa pokoju i błogosławieństwa wojny, zostały wskazane źródła filozoficznego ujęcia wojny, które zaproponowali autorzy związani $z$ Moskiewskim Towarzystwem Religijno-Filozoficznym im. Włodzimierza Sołowjowa. Bohun rozpoczyna od omówienia opinii na temat fenomenu wojny, prezentowanych przez dwóch twórców uznawanych za prekursorów rosyjskiego renesansu religijno-filozoficznego - Fiodora Dostojewskiego i Włodzimierza Sołowjowa. W gronie tym zabrakło trzeciego $z$ prekursorów, Mikołaja Fiodorowa, który wypowiadał się na temat wojny i do którego w latach 1914-1917 nawiazywał m.in. Mikołaj Bierdiajew ${ }^{24}$. Michał Bohun poświęcił mu jedynie obszerny przypis w rozdziale Czas Słowian! ${ }^{25}$.

\footnotetext{
${ }^{23}$ Por. m.in. M. Bierdiajew: Słowianofilstwo i idea słowiańska, przekład T. Herbich, „Teologia Polityczna" 2015-2016, nr 8, s. 229-234.

${ }_{24}$ Por. idem: Пророчества Н.Ф.Федорова о войне, „Биржевые ведомости” nr 15027, 15 sierpnia 1915; idem: Религия воскрешения ("Философия общего дела" Н.Ф.Федорова), w: idem: Собрание сочинений, t. 3: Типы религиозной мысли в России, ҮMCA-Press, Париж 1989, s. 242-301 (artykuł pierwotnie opublikowany w czasopiśmie „Русская мысль” w lipcu 1915 roku).

${ }^{25}$ Por. M. Bohun: Oczyszczenie..., s. 152.
} 
Autor wspomina natomiast pacyfizm Lwa Tołstoja, który stanowił negatywny punkt odniesienia zarówno dla Sołowjowa, jak i jego duchowych następców, nie przeprowadza jednak szczegółowej rekonstrukcji jego założeń ideowych, czego należało się spodziewać. W dalszej części rozdziału autor prezentuje stanowiska Erna, Bułgakowa i Trubieckoja, kończy go zaś obszernym fragmentem poświęconym ocenie wojny i jej moralnego oraz historycznego sensu dokonanej przez filozofa-artylerzystę, Fiodora Stiepuna. Zakończenie rozdziału staranną analiza poglądów Stiepuna zdaje się wynikać ze wspomnianej wcześniej chęci wykroczenia poza ścisły horyzont moskiewskiego neosłowianofilstwa i przeniesienia rozważań na grunt uniwersalnego doświadczenia wojny. Stiepun został ukazany jako filozof szukający drogi pośredniej między pacyfizmem Tołstoja a apologia wojny Dostojewskiego, $z$ jednej strony akceptujący Tołstojowskie utożsamienie wojny $z$ morderstwem, $z$ drugiej zaś uznający, że moralny sens wojny polega na tym, że jej totalność wiąże się $z$ idea odpowiedzialności za wszystko i za wszystkich, wypowiedziana przez starca Zosimę w Braciach Karamazow.

\section{Ocena książki ze względu na jej zakresy tematyczne}

Oczyszczenie przez burzę należy ocenić ze względu na trzy wyróżnione przeze mnie zakresy tematyczne. Pierwszy $z$ nich to znaczenie I wojny światowej w kulturze umysłowej Europy poczatku $\mathrm{XX}$ wieku, które jest analizowane na przykładzie roli, jaką wojna odegrała w dyskusjach prowadzonych w Rosji. Autor przekonujacco wykazał, że rosyjskie doświadczenie I wojny światowej jest częścią doświadczenia ogólnoeuropejskiego i wielokrotnie udowodnił na szczegółowych przykładach, w jaki sposób wspólne całej Europie motywy (takie jak np. opozycja „męskie” - „żeńskie”, która miała opisywać zasadnicze właściwości porównywanych stanowisk, kultur i narodów ${ }^{26}$ ) funkcjonowały w kontekście rosyjskim. Dzięki

${ }^{26}$ Por. ibidem, s. 102-106. 
temu rosyjskie doświadczenie wojny nie tylko mieści się $\mathrm{w}$ doświadczeniu ogólnoeuropejskim, lecz może je także reprezentować - oczywiście w ograniczonym zakresie, co zreszta dotyczy każdego doświadczenia narodowego ze względu na jego partykularny charakter. To zaś sprawia, że monografia Bohuna osiagnęła również jeden $z$ zasadniczych celów, które postawił przed nią jej autor: przypomina o wojnie, która zarówno w polskiej, jak i w rosyjskiej pamięci nie posiada takiej rangi, na jaka zasługuje. Na realizację tego celu wpływa również formalna i językowa atrakcyjność książki, dzięki której moga ja czytać osoby bez wykształcenia filozoficznego. Warto także podkreślić, że wyartykułowana w zakończeniu monografii idea filozofii jako pamięci wydaje się realizować postulat jedności teorii i praktyki w badaniu filozoficznym.

Takie podejście stwarza interesujace perspektywy dla badań porównawczych, które powinny ujawnić również wyjątkowość i niepowtarzalność rosyjskiego doświadczenia I wojny światowej. Owa wyjątkowość jest związana $z$ faktem, że w pewnym sensie wojna dla Rosjan nie skończyła się ani wraz z pokojem brzeskim, ani tym bardziej w 1917 roku, lecz trwała przez kolejne dziesięciolecia, a swój kres osiagnęła dopiero w 1991 roku. Nie została ona przepracowana przez rosyjską kulturę w sposób, który można byłoby porównywać $z$ wysiłkiem intelektualnym, jaki dokonał się na Zachodzie.

Drugi zakres tematyczny książki obejmuje badania nad postawa środowiska skupionego wokół Moskiewskiego Towarzystwa Religijno-Filozoficznego im. Włodzimierza Sołowjowa wobec I wojny światowej. Michał Bohun przedstawił obszerna, szczegółowa i bardzo rzetelna rekonstrukcję najważniejszych zagadnień rozwijanych przez moskiewskich neosłowianofilów w pismach bezpośrednio zwiąanych $z$ wybuchem i przebiegiem I wojny światowej. Co niemniej ważne, podjęty przez niego temat został niesłusznie zmarginalizowany $\mathrm{w}$ badaniach poświęconych historii filozofii rosyjskiej. Publicystyka wojenna takich autorów jak Bierdiajew czy Bułgakow, jest często pomijana i odgrywa relatywnie niewielka rolę w poświęconych im monografiach. Nieobecność tej problematyki 
charakteryzuje również najważniejsze syntezy dziejów myśli rosyjskiej. Ta marginalizacja nie wynika jednak $z$ nieważności tego zagadnienia. Jak zauważyłem na początku niniejszego artykułu, lata 1905-1917 daja się wyróżnić nie tylko jako osobny okres w rosyjskiej historii politycznej, lecz także jako kluczowy etap w rozwoju samoświadomości filozoficznej większości głównych przedstawicieli rosyjskiego srebrnego wieku. W procesie tym doświadczenie wojenne, które ugruntowało poczucie odrębności od niemieckiej kultury filozoficznej i ostatecznie potwierdziło zasadność poszukiwań własnej drogi rosyjskiej filozofii, odegrało niebagatelną rolę.

$Z$ tym jednak wiąże się również jeden $z$ najpoważniejszych braków recenzowanej monografii. Choć we wstępie (nieprzypadkowo zatytułowanym Niezamilkłe muzy) autor sygnalizuje, że podczas I wojny światowej oprócz publikacji stanowiących bezpośredni przedmiot jego zainteresowania powstawały także dzieła o znaczeniu ściśle teoretycznym, kluczowe w całym dorobku autorów, takich jak Ern (Filozofia Giobertiego), Bułgakow (Światłość niezachodzaca), Bierdiajew (Sens twórczości) czy Trubieckoj (Sens życia), i choć niejednokrotnie cytuje fragmenty tych tekstów ( $z$ wyjątkiem praktycznie nieprzywoływanej książki Erna o Giobertim), to jednak nigdzie nie rozważa problemu o zasadniczym znaczeniu dla badań nad pismami tych autorów $z$ lat 1914-1917, tj. zagadnienia związku między ich artykułami, w których reagowali na bieżące wydarzenia zwiazane $z$ I wojna światowa oraz poszukiwali jej duchowych źródeł, a dokonywanymi w wymienionych dziełach odkryciami o ściśle teoretycznym znaczeniu. Czy istnieje związek między gruntowna rewizja i krytyka niemieckiego idealizmu, przedstawiona przez Bułgakowa w Światłości niezachodzacej, a omawianymi przez Bohuna pismami? Czy odkrycie jednoznacznie krytykowanej przez Erna mistyki niemieckiej (Mistrza Eckharta, Anioła Ślązaka i Jakuba Böhmego), które legło u podstaw projektu filozoficznego zarysowanego przez Bierdiajewa w Sensie twórczości, nie było jedna $z$ fundamentalnych przyczyn ideowej odrębności tego filozofa od reszty środowiska i czy ta odrębność nie ma tym samym 
głębszego i bardziej fundamentalnego charakteru niż sugerowany przez autora monografii? Wydaje się, że źródeł zarówno polemiki antysłowianofilskiej Bierdiajewa, jak i wyrażonego w niej narastającego poczucia odrębności od własnego środowiska należy upatrywać w odmiennym rozpoznaniu fundamentów kultury niemieckiej. Oznaczałoby to, że polemika antysłowianofilska nie miała jedynie względnych podstaw, lecz wynikała $z$ pewnej istotnej różnicy między Bierdiajewem a Ernem, Iwanowem czy Bułgakowem.

Odpowiedzi na te zasadnicze dla historii filozofii pytania nie znajdziemy w Oczyszczeniu przez burzę. Wydaje się, że nie jest to przypadkowe i ujawnia się w tym ważne uwarunkowanie, któremu jest poddana monografia Bohuna, sprawiające, że można rozwinąć podjęte przez niego badania. Dla niemałej części polskich studiów poświęconych dziejom filozofii rosyjskiej jest charakterystyczne, że wyrastaja one $z$ założeń metodologicznych przyjętych $\mathrm{w}$ pracach Andrzeja Walickiego, wprost umiejscawiającego swoje badania w nurcie historii idei, którego nie da się sprowadzić do ściśle pojętej historii filozofii. Nieuwzględnienie wymienionych pytań jest bezpośrednio związane $z$ faktem, że również Oczyszczenie przez burze zbliża się do tego nurtu badań, $z$ czego zresztą wynikają również najmocniejsze strony tej monografii - wśród nich przede wszystkim to, że w książce udało się „zarysować pewien stan samowiedzy elity umysłowej państwa carów doby Wielkiej Wojny"27.

Trzeci zakres tematyczny obejmuje dorobek filozoficzny Włodzimierza Erna. Zgodnie $z$ tym, co zasygnalizowałem wyżej, podejmujac ten watek, książka Bohuna uzupełniła bardzo ważną lukę nie tylko w polskich, ale również $\mathrm{w}$ światowych badaniach poświęconych rosyjskiemu renesansowi religijno-filozoficznemu. Oczyszczenie przez burzę przywróciło właściwe miejsce jednemu $z$ najbardziej zapomnianych współcześnie rosyjskich filozofów religijnych poczatku XX wieku ${ }^{28}$.

\footnotetext{
${ }^{27}$ Ibidem, s. 11.

${ }^{28}$ Michał Bohun podkreślił wkład Erna w rozwój rosyjskiej filozofii religijnej w latach 1905-1917, por. ibidem, s. 16-19. Należy odnotować, że po wydaniu Oczyszczenia przez burzę
} 
W prezentacji poglądów Erna Bohun nieco ogranicza jego dorobek (nie omawia przede wszystkim publikacji poświęconych włoskim ontologistom oraz jego studium o Platonie), co jednak wydaje się uzasadnione ze względu na główny temat monografii. $Z$ pewnościa należało natomiast wspomnieć o pojawiającej się $\mathrm{w}$ artykule Sens ontologizmu Giobertiego $w$ zwiazku $z$ problemami współczesnej filozofii dosyć pozytywnej (choć niepozbawionej elementów krytycznych) opinii na temat fenomenologii Husserla ${ }^{29}$. Najpoważniejsze ograniczenia dotycza jednak treści drugiego rozdziału, w którym Michał Bohun powinien bardziej uwypuklić to, że spór o Logos stał się jednym $z$ katalizatorów (podejmowanych również wcześniej, lecz na mniejszą skalę) prób rewizji zasadniczych kierunków ówczesnej myśli (w tym zwłaszcza neokantyzmu oraz głównych nurtów dziewiętnastowiecznej filozofii niemieckiej), które zdominuja rosyjska filozofię religijna przynajmniej do 1917 roku i odegraja niebagatelna rolę $\mathrm{w}$ procesie kształtowania się samoświadomości filozoficznej srebrnego wieku. Przyczyna niedostatecznego uwypuklenia tego faktu jest to, że omawiany rozdział - oprócz rekonstrukcji stanowiska neokantystów i popierającego ich Siemiona Franka, czyli osób, $z$ którymi Ern polemizował ogranicza się do prezentacji poglądów autora Walki o Logos i tym samym nie przywołuje publikacji jego ideowych sprzymierzeńców, takich jak choćby wydana w 1911 roku Filozofia wolności Mikołaja Bierdiajewa czy późniejsza o rok jego monografia o Aleksym Stiepanowiczu Chomiakowie. $Z$ tą druga książka Bierdiajewa wręcz należałoby skonfrontować monografię Erna o Grigoriju Skoworodzie - obie prace zostały opublikowane w podobnym czasie i wpisywały się w charakterystyczny dla środowiska skupionego wokół wydawnictwa Put' zamiar przypomnienia rodzimych tradycji filozofii religijnej.

Ernowi zostały również poświęcone obszerne fragmenty pracy Marka Kity, por. M. Kita: Logos większy niż ratio. Dwa świadectwa chrześcijańskiego modelu racjonalności u progu epoki współczesnej, Wydawnictwo WAM, Kraków 2012.

${ }_{29}$ Por. В.Ф. Эрн: Смысл онтологизма Джоберти в связи с проблемами современной философии, w: idem: Сочинения..., s. 409, 411-412. 
Co niemniej ważne, we wspomnianym, drugim rozdziale książki autor rekonstruuje opozycję między logizmem a racjonalizmem na podstawie tekstów, które weszły w skład wydanej w 1911 roku Walki o Logos, oraz książki o Skoworodzie. Pozwala mu to scharakteryzować kluczowe założenia i twierdzenia logizmu oraz uwypuklić najważniejsze i kontradyktoryjne cechy obu stanowisk. Choć dokładna i stojaca na wysokim poziomie rekonstrukcja wprowadza czytelnika w podstawy filozofii Erna, to wydaje się, że należało uwzględnić przynajmniej trzy dodatkowe artykuły rosyjskiego filozofa, które pozwoliłyby nie tylko omówić rezultaty jego krytyki kantyzmu, lecz także szczegółowo zrekonstruować jej przebieg - Krytykę kantowskiego pojęcia prawdy ${ }^{30}$, Naturę myśli ${ }^{31}$ i Nature myśli naukowej ${ }^{32}$.

Mimo że należy zdecydowanie docenić fakt, że Oczyszczenie przez burze jest pierwsza i dotychczas jedyna polskojęzyczna monografia, której głównym bohaterem jest Włodzimierz Ern, to jednak można wskazać przynajmniej jedno poważne ograniczenie wynikające $z$ samej konstrukcji wywodu, tzn. $z$ przyznania autorowi Walki o Logos głównej roli w monografii poświęconej stanowisku moskiewskich neosłowianofilów wobec I wojny światowej. Choć problematyka podejmowana w rozdziałach Czas Słowian! oraz Droga ku powszechności: Konstantynopol i sprawa polska skłania do rekonstrukcji przedwojennego sporu o mesjanizm, Michał Bohun w żadnej części swojej pracy tego nie uczynił. Pominięcie sporu o mesjanizm wynika $z$ faktu, że to nie Ern, ale Bierdiajew i Trubieckoj byli głównymi protagonistami w tej dyskusji, w której głos zabierali także m.in. Iwanow i Bułgakow. Mimo to należało

\footnotetext{
${ }^{30}$ Zob. idem: Критика кантовского понятия истины, w: Философрский сборник. Аьву Михайловичу Аопатину к 30-летию научно-педагогической деятельности (1881-1911) от Московского психологического общества, Москва 1912, s. 49-61; por. ten sam artyku1 w nowszym wydaniu: idem: Критика кантовского понятия истины, w: А.И. Абрамов, В.А. Жучков, А.А. Ермичев (red.): Кант: pro et contra, Издательство Русской Христианской гуманитарной академии, Санкт-Петербург 2005, s. 728-739.

${ }^{31}$ Zob. idem: Природа мысли, „Богословский Вестник” 1913, nr 3, s. 500-531; nr 4, s. 803-843; nr 5, s. 107-120.

32 Zob. idem: Природа научной мысли, „Богословский Вестник” 1914, nr 1, s. 154-173; nr 2, s. 342-368.
} 
omówić ten spór w Oczyszczeniu przez burzę, była to bowiem jedna $z$ dwóch najważniejszych dyskusji toczonych w Moskiewskim Towarzystwie Religijno-Filozoficznym im. Włodzimierza Sołowjowa bezpośrednio przed I wojna światowa, która fundamentalnie wpłynęła na poglądy prezentowane przez to środowisko w latach 1914-1917. Wydaje się ponadto, że część pracy, w której autor książki prezentuje stanowiska zajmowane przez moskiewskich neosłowianofilów w tzw. kwestii polskiej, należało dopełnić obszerniejszymi rozważaniami poświęconymi recepcji głównych idei polskiego mesjanizmu w ich pismach.

\section{Zakończenie}

Powyższy artykuł recenzyjny nie pozostawia wątpliwości, że wraz $z$ wydaną niecałe dziesięć lat temu monografią Michała Bohuna polscy badacze myśli rosyjskiej otrzymali wysokiej klasy studium poświęcone postawom zajmowanym przez przedstawicieli Moskiewskiego Towarzystwa Religijno-Filozoficznego im. Włodzimierza Sołowjowa wobec I wojny światowej. Wymienione ograniczenia książki świadczą natomiast o tym, że należy rozwinąć badania, których celem będzie określenie zasadniczych kierunków rozwoju rosyjskiego renesansu religijno-filozoficznego w latach 1905-1917 i opisanie roli, jaka doświadczenie wojenne odegrało w dokonującej się wówczas krystalizacji stanowisk. Okres ten, którego lata 1914-1917 są integralną częścią, należy uważać za newralgiczny w procesie kształtowania się oryginalnego oblicza rosyjskiej filozofii religijnej w I połowie XX wieku.

\section{Tomasz Herbich}

Tomasz Herbich - doktorant w Instytucie Filozofii Uniwersytetu Warszawskiego oraz na Wydziale Teologicznym Uniwersytetu Kardynała Stefana Wyszyńskiego w Warszawie. Członek redakcji „Teologii Politycznej”, „Rocznika Historii Filozofii Polskiej” oraz „Słowa Krzyża”. 